\title{
Considerations for long-term anticoagulant therapy in patients with venous thromboembolism in the novel oral anticoagulant era
}

\author{
This article was published in the following Dove Press journal: \\ Vascular Health and Risk Management \\ I0 February 2016 \\ Number of times this article has been viewed
}

\author{
Peter P Toth ${ }^{1-3}$ \\ 'CGH Medical Center, Sterling, IL, \\ 2Johns Hopkins University School of \\ Medicine, Baltimore, MD, ${ }^{3}$ University \\ of Illinois School of Medicine, Peoria, \\ IL, USA
}

\begin{abstract}
Background: Patients who have had a venous thromboembolic event are generally advised to receive anticoagulant treatment for 3 months or longer to prevent a recurrent episode. Current guidelines recommend initial heparin and an oral vitamin $\mathrm{K}$ antagonist (VKA) for long-term anticoagulation. However, because of the well-described disadvantages of VKAs, including extensive food and drug interactions and the need for regular anticoagulation monitoring, novel oral anticoagulants (NOACs) have become an attractive option in recent years. These agents are given at fixed doses and do not require routine coagulation-time monitoring. The NOACs are discussed in this review with regard to the needs of patients on long-term anticoagulation.

Methods: Current guidelines from Europe and North America that refer to the treatment of deep vein thrombosis and/or pulmonary embolism are included, as well as published randomized Phase III clinical trials of NOACs. PubMed searches were used for sourcing case studies of long-term anticoagulant treatment, and results were filtered for human application and screened for relevance.

Conclusion: NOAC-based therapy showed a similar efficacy and safety profile to heparins/ VKAs but without the need for regular anticoagulation monitoring or dietary adjustments, and can be taken as a fixed-dose regimen once or twice daily. This represents a significant step forward in facilitating the management of long-term anticoagulation therapy. Furthermore, in the EINSTEIN studies, improved patient satisfaction was documented with the NOAC rivaroxaban, which may result in better adherence to therapy and an overall reduction in the incidence of recurrent venous thromboembolism.
\end{abstract}

Keywords: anticoagulation, patient needs, vitamin $\mathrm{K}$ antagonist, direct thrombin inhibitor, direct Factor Xa inhibitor, deep vein thrombosis, pulmonary embolism

\section{Introduction}

Patients who have had a venous thromboembolic event, that is, proximal deep vein thrombosis (DVT) or pulmonary embolism (PE), are generally advised to receive anticoagulant treatment for a minimum of 3 months. ${ }^{1,2}$ The treatment period may be further extended, or even continued indefinitely, based on assessment of the individual's risks of recurrent venous thromboembolism (VTE) and bleeding. The risk of secondary complications, such as post-thrombotic syndrome and chronic thromboembolic pulmonary hypertension, may also have an impact on the prospective treatment duration. The periods of VTE treatment described by the American College of Chest Physicians (ACCP) are initial (the first $\sim 7$ days), long-term ( $\sim 7$ days to
Correspondence: Peter P Toth

CGH Medical Center, I0I East Miller Road, Sterling, IL 6108I, USA

Tel +l 8156325093

$\mathrm{Fax}+\mathrm{I} 8156265947$

Email peter.toth@cghmc.com 
$\sim 3$ months), and extended ( $\sim 3$ months onward), ${ }^{2}$ but many similar guidelines, such as those from the European Society of Cardiology (ESC), ${ }^{1}$ simply categorize treatment as initial and long-term.

At present, there is no clear guidance on the optimal length of anticoagulant therapy for the prevention of recurrent VTE, except that the duration should be individualized based on the balance between the risks of a secondary event in patients who stop receiving anticoagulation and the risk of bleeding with continued therapy. Guidelines generally recommend initial treatment with parenteral unfractionated heparin, low-molecular-weight heparin (LMWH) or fondaparinux, overlapping with and transitioning to an oral vitamin $\mathrm{K}$ antagonist (VKA), such as warfarin, for long-term anticoagulation. ${ }^{1,2}$ This dual-drug approach is required because VKAs take several days to reach therapeutic levels of anticoagulation, as determined by the international normalized ratio (INR). ${ }^{3}$ Regular coagulation-time monitoring and dose adjustments to maintain the INR in the therapeutic range of 2.0-3.0 are required for the duration of therapy, because the pharmacodynamic effects of VKAs are highly variable and affected by diet, medications, genetic polymorphisms, and other factors. In recent years, the novel oral anticoagulants (NOACs) dabigatran (a direct thrombin inhibitor) and rivaroxaban, apixaban, and edoxaban (direct Factor Xa inhibitors) have been developed as treatment alternatives to VKAs. They offer a more predictable pharmacological profile and can be given at fixed doses without the need for routine coagulation monitoring. ${ }^{4}$ These agents have all undergone successful clinical trials for VTE treatment, given either as single-drug therapies (rivaroxaban, apixaban) or after initial parenteral anticoagulation (dabigatran, edoxaban). Dabigatran, rivaroxaban, apixaban, and, most recently, edoxaban are approved for the treatment of acute DVT and PE and prevention of recurrent VTE in the USA and European Union.

This review discusses the risk factors for VTE recurrence and treatment-associated bleeding, current guidelines, and clinical trial data on the use of NOACs for the treatment of acute DVT and PE and prevention of recurrent VTE, as well as the needs of patients on long-term anticoagulation. Case studies are included to illustrate situations in which patients may require long-term anticoagulation and how this can be managed.

\section{Methods}

Current European and North American guidelines for the treatment of DVT and/or PE were reviewed, along with published randomized Phase III clinical studies of NOACs. Case studies of long-term anticoagulant treatment were sourced via PubMed searches using the search strings [case AND warfarin AND cancer], [case AND PCC OR aPCC OR FVIIa AND reversal], and [case AND long-term anticoagulation AND X] in which X was replaced by cancer, antiphospholipid, antithrombin, Factor V Leiden, or protein $\mathrm{C}$ deficiency. Results were filtered to ensure that they were case reports and applied to humans and were further refined by a review of each abstract for relevance.

\section{Balancing the risks of recurrent VTE and bleeding}

The risk of recurrent VTE increases when anticoagulation therapy is stopped, particularly if a patient has certain predisposing risk factors (Figure 1). ${ }^{1,2}$ Risk factors for recurrent VTE include recent surgery and/or trauma, active cancer, advanced age, male sex, obesity, immobility, and thrombophilia. Some of these risk factors, such as surgery and immobility, may be reversible or transient, and it is unlikely that anticoagulation would be continued beyond the point at which the influence on VTE risk ceases. However, patients with a first unprovoked proximal DVT and/or PE, a second unprovoked VTE, or with ongoing comorbidities such as cancer may require long-term anticoagulation. The presence of residual vein thrombosis after initial anticoagulant treatment may be associated with an increased risk of recurrent DVT, although this is not clear. ${ }^{5}$ In patients with a previous unprovoked VTE, the estimated risk of VTE recurrence was more than double for patients with elevated D-dimer levels compared with those with normal D-dimer levels, and recurrence may be particularly likely in men with high D-dimer levels. ${ }^{6}$ However, the use of D-dimer testing to predict VTE recurrence is controversial. Genetic thrombophilia (eg, protein C, protein S, or antithrombin deficiency; prothrombin G20210A mutation; Factor V Leiden) can increase the risk of VTE recurrence, and patients with these mutations are therefore often recommended to receive lifelong anticoagulation (Table 1). ${ }^{1,2}$

Several prediction models have been developed to attempt to quantify the most important risk factors for DVT recurrence. Rodger et al identified hyperpigmentation, edema/ redness of the leg, D-dimer $\geq 250 \mu \mathrm{g} / \mathrm{L}$ while receiving anticoagulation, body mass index $\geq 30 \mathrm{~kg} / \mathrm{m}^{2}$, and age $\geq 65$ years as important factors for women with previous VTE and found that patients with two or more of these factors had a high risk of VTE recurrence. ${ }^{7}$ The authors of the Vienna prediction model found that age, sex, location of VTE, body mass index, Factor V Leiden, prothrombin G20210A mutation, 


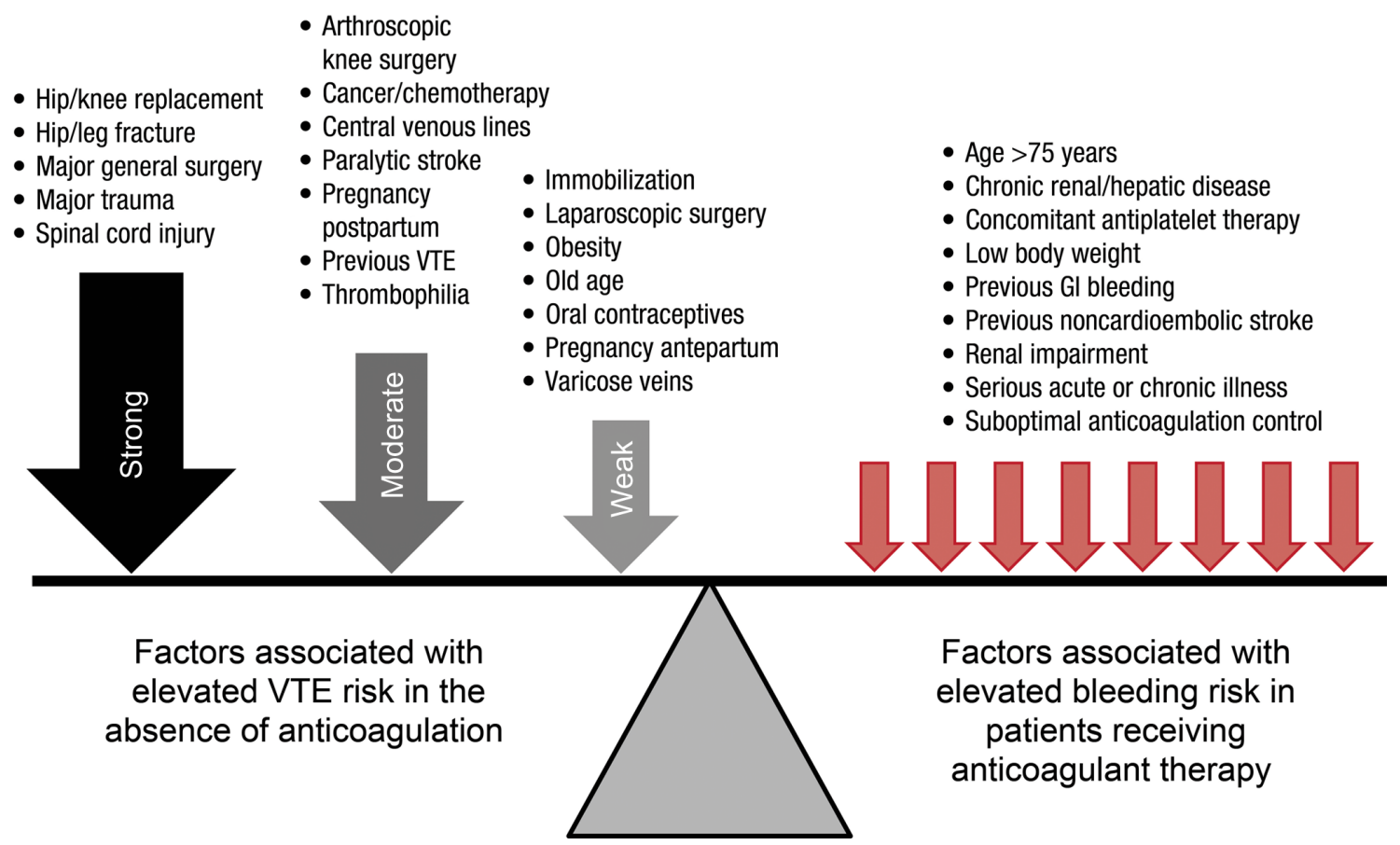

Figure I The balance between the risk of recurrent venous thromboembolism and bleeding events.

Notes: Data from Konstantinides et al' and Kearon et al. ${ }^{2}$

Abbreviations: $\mathrm{Gl}$, gastrointestinal; VTE, venous thromboembolism.

D-dimer concentration, and in vitro thrombin generation affected VTE recurrence rates, and they formulated a risk score accordingly. ${ }^{8}$ The simple D-dimer, Age, Sex, Hormonal therapy (DASH) score assigns one point to each of the following: elevated D-dimer after stopping anticoagulation, age $<50$ years, male sex, and VTE not associated with hormonal therapy (for women). Patients with a score of 0 or 1 are at low risk of recurrence $(3.1 \% /$ year), those with a score of 2 are at moderate risk (6.4\%/year), and those with a score of 3 or above are at high risk (12.3\%/year). ${ }^{9}$ However, this scoring system requires further validation.

All anticoagulants carry a risk of bleeding owing to their mode of action. In addition, there are certain patient groups that are predisposed to an increased risk of bleeding when receiving anticoagulant treatment (Figure 1). ${ }^{2}$ These include elderly patients, those with renal impairment, patients with low body weight, and those with a history of gastrointestinal bleeding. Previous noncardioembolic stroke, chronic renal or hepatic disease, serious acute or chronic illness, and concomitant antiplatelet therapy are all also implicated as factors that increase the risk of bleeding. Patients who have poor anticoagulant control when receiving VKAs, which may be a result of suboptimal coagulation monitoring, ${ }^{3}$ are also at elevated risk if their INR is persistently above the recommended upper boundary of 3.0. ${ }^{2}$

\section{Current guidelines on the duration of antithrombotic therapy}

Current guidelines on the anticoagulant treatment of VTE are summarized in Table 2. ${ }^{1,2,10}$ The ACCP recommends that patients with unprovoked DVT of the leg (isolated distal or proximal) or unprovoked but hemodynamically stable PE receive at least 3 months of anticoagulant treatment. ${ }^{2}$ After 3 months, these patients should be evaluated for the risk and benefit of continued therapy. In patients with unprovoked VTE, extending anticoagulant therapy beyond 3 months is recommended only if the associated risk of bleeding remains low. In patients who experience DVT or PE and do not have cancer, VKAs are preferred to LMWH for long-term therapy, with LMWH as a second choice over NOACs (at the time the ACCP guidelines were issued, there was a considerably smaller body of published clinical data on NOACs than is now the case). In patients with DVT and cancer, LMWH is preferred, with VKAs as a second choice over NOACs. ${ }^{2} \mathrm{LMWH}$ is also indicated in pregnant women because it does not cross the placenta. ${ }^{10}$

Although the ESC guidelines deal primarily with $\mathrm{PE}$, the recommendations are similar to those of the ACCP (Table 2). ${ }^{1}$ In patients with a first unprovoked event and a low risk of bleeding, an indefinite duration of anticoagulant therapy is recommended provided that this is consistent with the patient's preference. Most patients with a second 
Table I Thrombophilia and development of thromboembolism

\begin{tabular}{|c|c|c|c|c|}
\hline Reference & Presentation & $\begin{array}{l}\text { Underlying risk factor for } \\
\text { recurrent thrombosis }\end{array}$ & Treatment & Outcome \\
\hline Citro et $\mathrm{al}^{40}$ & $\begin{array}{l}\text { A 69-year-old woman who was } \\
\text { a heterozygote carrier of Factor } \\
\text { V Leiden mutation presented } \\
\text { to the emergency room with } \\
\text { the clinical scenario of massive } \\
\text { pulmonary embolism }\end{array}$ & $\begin{array}{l}\text { Factor V Leiden } \\
\text { heterozygosity }\end{array}$ & $\begin{array}{l}\text { - Unfractionated heparin } \\
\text { - Surgical treatment consisting } \\
\text { of complete excision of the thrombus } \\
\text { - Long-term anticoagulation treatment } \\
\text { (not specified) }\end{array}$ & $\begin{array}{l}\text { At I-year follow-up, } \\
\text { the patient was on long- } \\
\text { term anticoagulation } \\
\text { treatment and free of } \\
\text { thromboembolic events }\end{array}$ \\
\hline Cook et $\mathrm{al}^{41}$ & $\begin{array}{l}\text { A } 30 \text {-year-old, previously } \\
\text { healthy woman diagnosed with } \\
\text { acute, spontaneous, left-ovarian } \\
\text { vein thrombosis with proximal } \\
\text { extension into the renal vein }\end{array}$ & $\begin{array}{l}\text { Factor V Leiden } \\
\text { homozygosity }\end{array}$ & $\begin{array}{l}\text { Initial catheter-directed thrombolysis } \\
\text { with tissue plasminogen activator, } \\
\text { angioplasty of the left renal vein, } \\
\text { heparinoid treatment } \\
\text { - Long-term anticoagulation with } \\
\text { rivaroxaban }\end{array}$ & $\begin{array}{l}\text { Complete resolution of } \\
\text { thrombosis at } 3 \text { months; } \\
\text { no adverse effects or } \\
\text { bleeding reported }\end{array}$ \\
\hline Jukic et a $\mathrm{a}^{42}$ & $\begin{array}{l}\text { A case of cerebral sinus } \\
\text { thrombosis as a recurrent } \\
\text { thrombotic event in a patient } \\
\text { with heterozygous prothrombin } \\
\text { G202 I0A genotype after } \\
\text { discontinuation of oral } \\
\text { anticoagulation therapy }\end{array}$ & $\begin{array}{l}\text { Heterozygous } \\
\text { prothrombin } \\
\text { G20210A genotype }\end{array}$ & $\begin{array}{l}\text { Heparin and symptomatic therapy } \\
\text { were started. On the fifth day, warfarin } \\
\text { was included in the treatment } \\
\text { (maintained at the international } \\
\text { normalized ratio range of } 2-3 \text { ), and } \\
\text { heparin was excluded after } 8 \text { days }\end{array}$ & $\begin{array}{l}\text { Constantly improving } \\
\text { condition of the patient } \\
\text { and discharged after } \\
6 \text { weeks with } \\
\text { recommendation for } \\
\text { long-term use of warfarin }\end{array}$ \\
\hline Kim et al ${ }^{43}$ & $\begin{array}{l}\text { A } 35 \text {-year-old man who } \\
\text { developed superior mesenteric } \\
\text { venous thrombosis and portal } \\
\text { vein thrombosis showed } \\
\text { markedly decreased protein } C \\
\text { and S levels }\end{array}$ & $\begin{array}{l}\text { Protein } \mathrm{C} \text { and } \mathrm{S} \\
\text { deficiency }\end{array}$ & $\begin{array}{l}\text { - Heparin and total parenteral } \\
\text { nutrition was given } \\
\text { - } 3 \text { weeks after hospitalization, } \\
\text { the patient was fed orally and } \\
\text { heparin was replaced by warfarin }\end{array}$ & $\begin{array}{l}\text { The patient was } \\
\text { discharged } 27 \text { days } \\
\text { after admission and had } \\
\text { returned to work by the } \\
9 \text { month follow-up. Recent } \\
\text { protein C level was } 60 \% \\
\text { of control }\end{array}$ \\
\hline $\begin{array}{l}\text { Kshatriya } \\
\text { et } \text { al }^{44}\end{array}$ & $\begin{array}{l}\text { A } 55 \text {-year-old Caucasian man } \\
\text { with history of hypertension, } \\
\text { diabetes mellitus, protein } \\
\text { C deficiency, and deep vein } \\
\text { thrombosis presented with } \\
\text { typical angina }\end{array}$ & Protein C deficiency & $\begin{array}{l}\text { - Tomography and echocardiography } \\
\text { presented a mobile mass in the left } \\
\text { atrium } \\
\text { - Cardiac catheterization and } \\
\text { angiography indicated the presence } \\
\text { of a myxoma rather than a thrombus } \\
\text { - Cardiothoracic surgery was conducted } \\
\text { for excision of the left atrial mass }\end{array}$ & $\begin{array}{l}\text { Full recovery with } \\
\text { outpatient cardiology } \\
\text { follow-up. Angina } \\
\text { symptoms were } \\
\text { completely relieved, and } \\
\text { the patient was started } \\
\text { on anticoagulation with } \\
\text { warfarin for the history } \\
\text { of deep vein thrombosis }\end{array}$ \\
\hline
\end{tabular}

unprovoked VTE are also recommended to receive indefinite anticoagulation. ${ }^{1}$

\section{Prevention of recurrent VTE with NOACS: evidence from Phase III clinical trials}

Randomized, controlled Phase III clinical trials have been conducted to investigate the NOACs rivaroxaban, apixaban, edoxaban, and dabigatran for the treatment of acute VTE for periods of up to 12 months $^{11-16}$ and in extension studies for prevention of VTE recurrence for up to 3 years (Figure 2). ${ }^{11,17,18}$ A meta-analysis of the six acute treatment trials found a similar overall efficacy for the NOACs compared with standard therapy (relative risk $=0.89 ; 95 \%$ confidence interval $[\mathrm{CI}]=0.75-1.05)$, whereas in the three studies of extended treatment, NOACs were superior to placebo for the prevention of recurrent VTE (relative risk $=0.17 ; 95 \% \mathrm{CI}=0.12-0.24$ ). ${ }^{19}$ In the EINSTEIN DVT and EINSTEIN PE studies, rivaroxaban $15 \mathrm{mg}$ twice daily given for 21 days, followed by $20 \mathrm{mg}$ once daily for 3 months, 6 months, or 12 months (depending on physician evaluation of risk factors), was noninferior to standard parenteral anticoagulation/VKA for the prevention of recurrent VTE $(P<0.001$ for noninferiority in both studies and a pooled analysis). ${ }^{11,12,20}$ The EINSTEIN EXT study evaluated the efficacy and safety of rivaroxaban for extended treatment of DVT (beyond the currently recommended treatment duration). Patients who had completed either the EINSTEIN DVT or EINSTEIN PE study or who had received VKA therapy outside of these trials for 6 months -12 months, and for whom the decision to stop or continue anticoagulation was 
Table 2 The US and European guidelines on the duration of anticoagulant treatment for venous thromboembolism

\begin{tabular}{|c|c|c|}
\hline \multirow[t]{2}{*}{ Patient and disease type } & \multicolumn{2}{|c|}{ Recommendations for duration of anticoagulant treatment } \\
\hline & ACCP $2012^{2}$ & ESC $2014^{\prime}$ \\
\hline $\begin{array}{l}\text { Patient with proximal DVT or hemodynamically } \\
\text { stable PE associated with transient risk factors }\end{array}$ & $\begin{array}{l}\text { VKA preferred over LMWH or NOAC } \\
\text { Treat for } 3 \text { months }\end{array}$ & Anticoagulant treatment for 3 months \\
\hline $\begin{array}{l}\text { Patient with unprovoked } \\
\text { proximal DVT or hemodynamically } \\
\text { stable PE }\end{array}$ & $\begin{array}{l}\text { VKA preferred over LMWH or NOAC } \\
\text { First or subsequent unprovoked VTE with } \\
\text { low/moderate bleeding risk: }>3 \text { months' } \\
\text { treatment }\end{array}$ & $\begin{array}{l}\text { First or subsequent } \\
\text { unprovoked PE with a low bleeding } \\
\text { risk: }>3 \text { months to indefinite } \\
\text { anticoagulant treatment }\end{array}$ \\
\hline Patient with isolated distal DVT & $\begin{array}{l}\text { Consider serial imaging rather than } \\
\text { anticoagulation to monitor for any clot } \\
\text { extension if symptoms are not severe or } \\
\text { clot extension is considered unlikely. Provide } \\
\text { anticoagulant treatment if symptoms are } \\
\text { severe or clot extends (recommended } \\
\text { therapy and durations as above) }\end{array}$ & Recommendations not provided \\
\hline VTE in a patient with active cancer & $\begin{array}{l}\text { LMWH preferred over } \\
\text { VKA: }>3 \text { months }\end{array}$ & $\begin{array}{l}\text { LMWH for 3-6 months, then } \\
\text { consider indefinite anticoagulation } \\
\text { or until cancer is in remission }\end{array}$ \\
\hline VTE in a pregnant woman & $\begin{array}{l}\text { LMWH preferred over UFH: } \\
\text { continue for a minimum of } 3 \text { months } \\
\text { and for at least } 6 \text { weeks postpartum }\end{array}$ & $\begin{array}{l}\text { LMWH preferred over UFH } \\
\text { Anticoagulation (VKA permitted } \\
\text { after birth) to continue for at least } \\
6 \text { weeks postpartum for a minimum } \\
\text { overall treatment duration of } 3 \text { months }\end{array}$ \\
\hline $\begin{array}{l}\text { VTE in a patient with severe renal } \\
\text { impairment }(\mathrm{CrCl}<30 \mathrm{~mL} / \mathrm{min})\end{array}$ & $\begin{array}{l}\text { UFH preferred over LMWH, } \\
\text { rivaroxaban, or dabigatran owing } \\
\text { to lack of renal clearance }\end{array}$ & $\begin{array}{l}\text { UFH preferred to LMWH owing } \\
\text { to short half-life and rapid reversal } \\
\text { by protamine }\end{array}$ \\
\hline Patient with PTS secondary to DVT & $\begin{array}{l}\text { Use of mechanical compression } \\
\text { (stockings, venous foot pump) }\end{array}$ & Recommendations not provided \\
\hline Patient with CTEPH secondary to PE & $\begin{array}{l}\text { Extended anticoagulation; } \\
\text { pulmonary thromboendarterectomy } \\
\text { if expertise available }\end{array}$ & $\begin{array}{l}\text { Pulmonary thromboendarterectomy } \\
\text { if operable, or targeted medical } \\
\text { therapy (riociguat) if not All patients } \\
\text { should receive lifelong anticoagulation }\end{array}$ \\
\hline Patient with inherited thrombophilia & Recommendations not provided & $\begin{array}{l}\text { Consider indefinite anticoagulant } \\
\text { treatment after a first unprovoked VTE }\end{array}$ \\
\hline
\end{tabular}

Note: Data from previous studies. ${ }^{1,2,10}$

Abbreviations: ACCP, American College of Chest Physicians; $\mathrm{CrCl}$, creatinine clearance; CTEPH, chronic thromboembolic pulmonary hypertension; DVT, deep vein thrombosis; ESC, European Society of Cardiology; LMWH, low-molecular-weight heparin; NOAC, novel oral anticoagulant; PE, pulmonary embolism; PTS, post-thrombotic syndrome; UFH, unfractionated heparin; VKA, vitamin K antagonist; VTE, venous thromboembolism.

at equipoise, were randomized to receive rivaroxaban $20 \mathrm{mg}$ once daily or placebo for a further 6 months or 12 months. ${ }^{11}$ Patients who received rivaroxaban had an $82 \%$ relative risk reduction for recurrent VTE compared with those in the placebo arm $(P<0.001)$.

Similar to rivaroxaban, apixaban was also studied as a single drug for the treatment of VTE compared with standard dual-drug therapy. In the AMPLIFY study, patients with VTE received 6 months of treatment with apixaban $(10 \mathrm{mg}$ twice daily for 7 days, followed by $5 \mathrm{mg}$ twice daily) or heparin/VKA; apixaban was noninferior to standard therapy for the prevention of recurrent VTE and VTE-related death $\left(P<0.001\right.$ for noninferiority). ${ }^{13}$ In AMPLIFY-EXT, patients who had completed AMPLIFY or had otherwise received 6 months-12 months of anticoagulant treatment, and for whom the decision to stop or continue anticoagulation was at equipoise, were randomized to apixaban $2.5 \mathrm{mg}$ or $5 \mathrm{mg}$ twice daily or placebo for a further 12 months. The lower and higher apixaban doses provided a respective $67 \%$ and $64 \%$ relative risk reduction for recurrent VTE plus all-cause mortality compared with placebo. ${ }^{17}$

Unlike rivaroxaban and apixaban, edoxaban was evaluated against warfarin for the treatment of acute VTE after all patients had received initial heparin. In the Hokusai-VTE study, patients received 3 months -12 months of therapy according to physician assessment and local guidelines. ${ }^{14}$ The edoxaban 


\section{A}

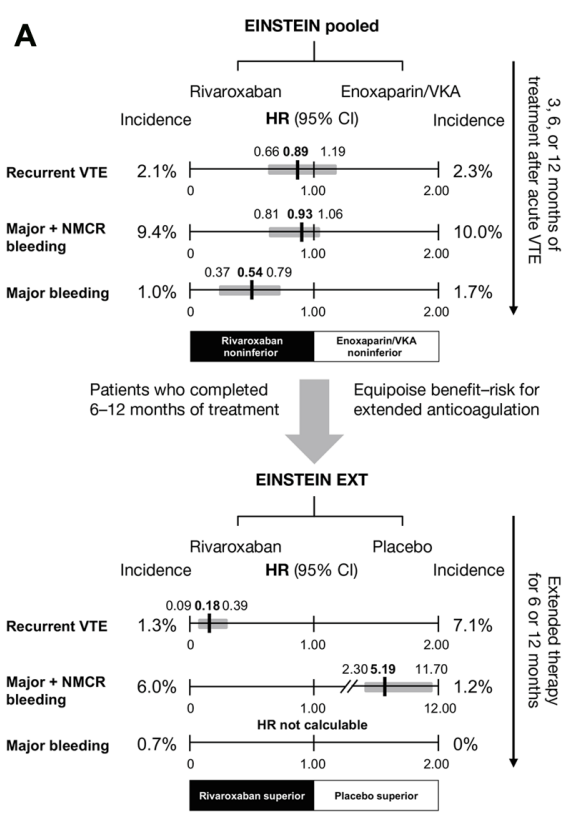

B

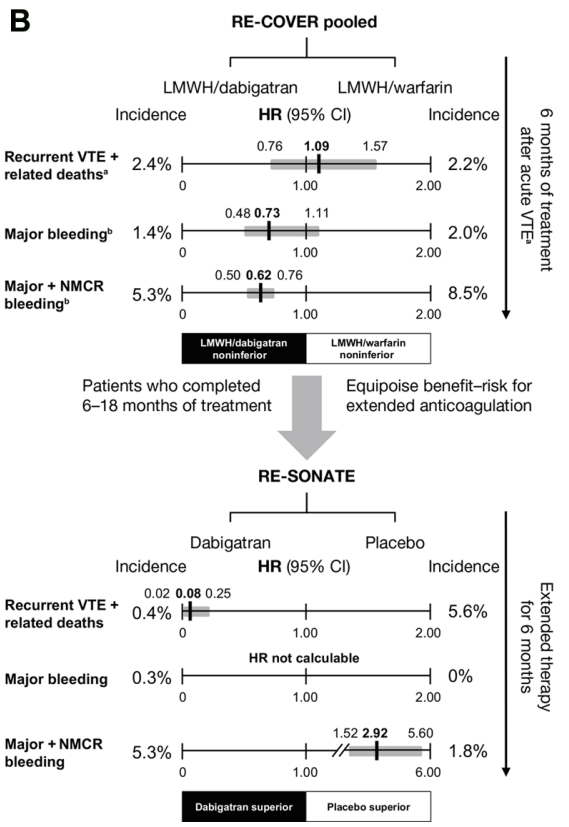

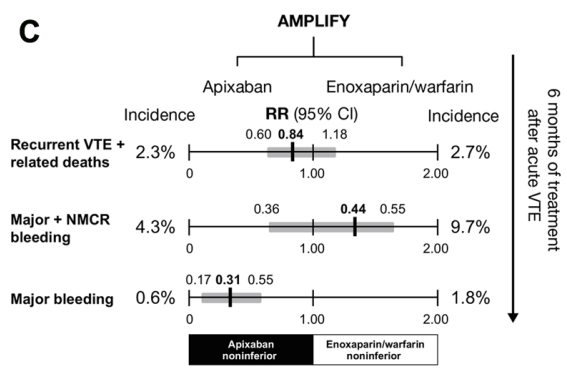

Patients who completed 6-12 months of treatment
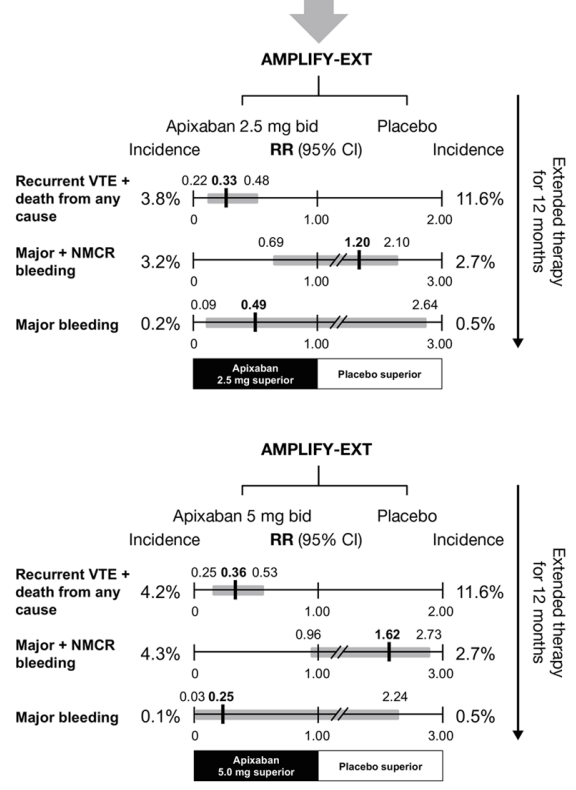

D
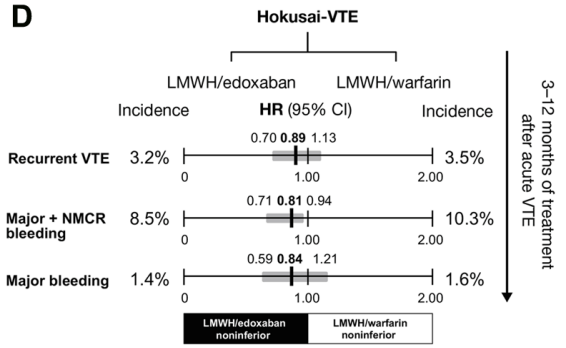

Figure 2 Principal efficacy and safety results of Phase III clinical trials of novel oral anticoagulants for the acute treatment of venous thromboembolism and long-term prevention of recurrence.

Notes: Data from the acute treatment of VTE are presented for the (A) pooled EINSTEIN DVT and EINSTEIN PE,, $11,12,20$ (B) pooled RE-COVER I and RE-COVER II, ${ }^{15,16}$ (C) AMPLIFY,13 and (D) Hokusai-VTE ${ }^{14}$ studies. Data from studies of extended treatment are also presented for the (A) EINSTEIN EXT," (B) RE-SONATE,18 and (C) AMPLIFY-EXT ${ }^{17}$ studies. Patients in the extension studies did not necessarily complete the equivalent acute treatment study first. ${ }^{a}$ Efficacy data were derived during the 6-month study period; bsafety data were obtained from the start of any study drug.

Abbreviations: bid, twice daily; Cl, confidence interval; HR, hazard ratio; LMWH, low-molecular-weight heparin; NMCR, nonmajor clinically relevant; RR, relative risk; VKA, vitamin $\mathrm{K}$ antagonist; VTE, venous thromboembolism.

arm (60 mg once daily, or $30 \mathrm{mg}$ once daily in patients with creatinine clearance $[\mathrm{CrCl}] 30 \mathrm{~mL} / \mathrm{min}-50 \mathrm{~mL} / \mathrm{min}$, body weight $\leq 60 \mathrm{~kg}$ or receiving concomitant treatment with potent P-glycoprotein [P-gp] inhibitors) was noninferior to standard heparin/warfarin for the incidence of recurrent symptomatic VTE ( $P<0.001$ for noninferiority). No extension study for edoxaban has yet been reported.
Dabigatran was evaluated in two studies for the treatment of acute VTE - RE-COVER and RE-COVER II - during which patients were randomized to receive dabigatran or VKA for 6 months. ${ }^{15,16}$ As in Hokusai-VTE, all patients received initial parenteral anticoagulation. Dabigatran $150 \mathrm{mg}$ twice daily was noninferior to VKA for the prevention of recurrent VTE and VTE-related death in a pooled analysis of the two 
studies (hazard ratio $[\mathrm{HR}]=1.09 ; 95 \% \mathrm{CI}=0.76-1.57) .{ }^{16}$ The RE-SONATE extension study with dabigatran had a similar design to EINSTEIN EXT and AMPLIFY-EXT: patients who had received 6 months -18 months of anticoagulation received a further 6 months of dabigatran $150 \mathrm{mg}$ twice daily or placebo. ${ }^{18}$ Dabigatran treatment led to a $92 \%$ relative risk reduction over placebo for the prevention of VTE or unexplained death $(P<0.001)$. In a separate extension study, RE-MEDY, long-term dabigatran was compared with long-term warfarin and was noninferior for the incidence of recurrent or fatal VTE ( $P=0.01$ for noninferiority). ${ }^{18}$

As a result of these studies, the ESC now recommends apixaban (2.5 mg twice daily), rivaroxaban (20 mg once daily), and dabigatran (150 mg twice daily, or $110 \mathrm{mg}$ twice daily for patients aged $\geq 80$ years or those receiving concomitant verapamil treatment) as alternatives to VKA therapy (except for patients with severe renal impairment) if extended anticoagulation treatment is necessary (Class IIa B level of recommendation). ${ }^{1}$

\section{Managing the risk of bleeding complications with long-term or extended NOAC treatment Bleeding risk and outcomes in clinical trials of NOACS}

In general, results from the Phase III trials of NOACs suggest that the rate of clinically relevant bleeding is approximately $10 \%$ with 6 months -12 months of VKA therapy and is somewhat lower with NOACs $(\sim 4 \%-9 \%)$ (Figure 2$).{ }^{1-16}$ In a meta-analysis of the acute treatment studies, the risk of major bleeding was significantly lower with the NOACs than standard therapy (relative risk $=0.63 ; 95 \% \mathrm{CI}=0.51-0.77$ ) and was not significantly increased versus placebo in studies of extended therapy. ${ }^{19}$ In the EINSTEIN DVT and EINSTEIN PE studies, major bleeding was defined as clinically overt and associated with a drop in hemoglobin levels of $\geq 2.0 \mathrm{~g} / \mathrm{dL}$, bleeding leading to the transfusion of $\geq 2$ units of red cells, or bleeding occurring in a critical site (eg, intracranial or retroperitoneal) or contributing to death. Nonmajor clinically relevant bleeding did not meet the criteria outlined for major bleeding but was overt and associated with medical intervention, interruption or discontinuation of a study drug, unscheduled contact with a physician, or general discomfort or impairment in daily life. ${ }^{11,12}$ In the EINSTEIN pooled analysis, there was a similar incidence of major plus nonmajor clinically relevant bleeding with rivaroxaban compared with standard therapy $(P=0.27)$; however, rivaroxaban was associated with a significant $46 \%$ relative reduction in the risk of major bleeding $(\mathrm{HR}=0.54$;
$95 \% \mathrm{CI}=0.37-0.79 ; P=0.002) .{ }^{20}$ In this pooled analysis, major bleeding was also relatively infrequent with rivaroxaban compared with standard therapy in some patient subgroups at high risk, including those defined as fragile (age $>75$ years, $\mathrm{CrCl} \leq 50 \mathrm{~mL} / \mathrm{min}$, or weight $\leq 60 \mathrm{~kg}$; $\mathrm{HR}=0.27,95 \%$ $\mathrm{CI}=0.13-0.54, P=0.011)$, and patients with an extensive clot burden $(\mathrm{HR}=0.36,95 \% \mathrm{CI}=0.18-0.73),{ }^{20}$ suggesting a broader benefit of treatment with rivaroxaban in high-risk subgroups. In the EINSTEIN EXT study, four of the 598 patients receiving rivaroxaban who were evaluated for safety had major bleeding (versus none with placebo; $P=0.11$ ). ${ }^{11}$ In AMPLIFY, the rates of major bleeding $(0.6 \%$ vs $1.8 \%, P<0.001)$ and major plus nonmajor clinically relevant bleeding (4.3\% vs $9.7 \%$, $P<0.001)$ were significantly lower with apixaban than with standard therapy, ${ }^{13}$ whereas in AMPLIFY-EXT the rates of both these outcomes were low and similar to placebo. ${ }^{17}$

In Hokusai-VTE, major bleeding occurred at a similar frequency in the edoxaban and standard therapy arms $(P=0.35)$, whereas major plus nonmajor clinically relevant bleeding was significantly lower with edoxaban $(P=0.004) .{ }^{14}$ Broadly the same definitions for major and nonmajor clinically relevant bleeding as for the EINSTEIN studies applied to AMPLIFY and Hokusai-VTE. ${ }^{13,14}$ In the pooled RE-COVER and RE-COVER II analysis, major bleeding occurred with a similar incidence in the dabigatran and standard therapy arms (HR $=0.73,95 \% \mathrm{CI}=0.48-1.11$ ), whereas the incidence of major plus nonmajor clinically relevant bleeding was significantly reduced with dabigatran $(\mathrm{HR}=0.62,95 \% \mathrm{CI}=0.50-0.76) .{ }^{16} \mathrm{In}$ the pooled RE-COVER population, the risk of major bleeding with dabigatran compared with warfarin appeared to increase with advancing age ( $P=0.010$ for interaction); overall, however, subgroup analyses showed that dabigatran had a consistent profile regardless of variations in patient demographics and risk factors. ${ }^{16}$ In the extension studies, there were two major bleeding events with dabigatran in RE-SONATE, and although the incidence of major plus nonmajor clinically relevant bleeding was significantly higher than that with placebo $(P=0.001)$, both major bleeding $(P=0.06)$ and major plus nonmajor clinically relevant bleeding $(P<0.001)$ were significantly lower with dabigatran than with warfarin in RE-MEDY. ${ }^{18}$ In RE-COVER and the extension studies, the same definition was applied for major bleeding, whereas for nonmajor clinically relevant bleeding a slightly different list of criteria applied. ${ }^{15,18}$

\section{Bleeding management and contraindications with NOACs}

Suggested algorithms for the management of bleeding in patients receiving NOACs are available, and these are largely similar to the well-established protocols for conventional 
Table 3 Summary of pharmacological properties of novel oral anticoagulants

\begin{tabular}{|c|c|c|c|c|}
\hline & Dabigatran & Rivaroxaban & Apixaban & Edoxaban \\
\hline Mode of action & $\begin{array}{l}\text { Direct thrombin } \\
\text { inhibitor }\end{array}$ & $\begin{array}{l}\text { Direct Factor Xa } \\
\text { inhibitor }\end{array}$ & $\begin{array}{l}\text { Direct Factor Xa } \\
\text { inhibitor }\end{array}$ & $\begin{array}{l}\text { Direct Factor Xa } \\
\text { inhibitor }\end{array}$ \\
\hline $\begin{array}{l}\text { Approved for VTE treatment } \\
\text { in Europe and the US? }\end{array}$ & Yes & Yes & Yes & Yes \\
\hline VTE treatment regimen & $\begin{array}{l}\text { Parenteral anticoagulant } \\
\text { for } 5-10 \text { days, then } \\
150 \mathrm{mg} \text { bid }\end{array}$ & $\begin{array}{l}15 \mathrm{mg} \text { bid for } \\
21 \text { days, then } \\
20 \mathrm{mg} \text { od }\end{array}$ & $\begin{array}{l}10 \mathrm{mg} \text { bid for } 7 \text { days, } \\
\text { then } 5 \mathrm{mg} \text { bid }\end{array}$ & $\begin{array}{l}\text { Parenteral } \\
\text { anticoagulant, then } \\
60 \mathrm{mg} \text { od }\end{array}$ \\
\hline $\begin{array}{l}\text { Dose adjustments for } \\
\text { VTE treatment }\end{array}$ & None tested & None mandated ${ }^{a}$ & None tested & $\begin{array}{l}30 \mathrm{mg} \text { od tested in } \\
\text { patients who were } \\
\text { expected to have an } \\
\text { increased bleeding risk }^{\mathrm{b}}\end{array}$ \\
\hline Food & $\begin{array}{l}\text { Take with or } \\
\text { without food }\end{array}$ & $\begin{array}{l}\text { VTE treatment doses } \\
\text { to be taken with food }\end{array}$ & $\begin{array}{l}\text { Take with or } \\
\text { without food }\end{array}$ & $\begin{array}{l}\text { Take with or } \\
\text { without food }\end{array}$ \\
\hline $\begin{array}{l}\text { Time to maximum } \\
\text { concentration/anticoagulant } \\
\text { effect (hours) }\end{array}$ & $0.5-2$ & $2-4$ & $3-4$ & $\mathrm{I}-2$ \\
\hline $\begin{array}{l}\text { Half-life in healthy individuals } \\
\text { (hours) }\end{array}$ & $12-14$ & $5-13$ & $\sim 12$ & $8-10$ \\
\hline $\begin{array}{l}\text { Proportion of drug subject } \\
\text { to renal clearancec }(\%)\end{array}$ & 85 & $33^{d}$ & 27 & 35 \\
\hline $\begin{array}{l}\text { Co-medications contraindicated/ } \\
\text { not recommended }\end{array}$ & $\begin{array}{l}\text { Strong P-gP } \\
\text { inhibitors and inducers }\end{array}$ & $\begin{array}{l}\text { Strong CYP3A4 } \\
\text { and P-gP inhibitors }\end{array}$ & $\begin{array}{l}\text { Strong CYP3A4 } \\
\text { and P-gP inhibitors }\end{array}$ & Strong P-gp inhibitors \\
\hline
\end{tabular}

Notes: ${ }^{\mathrm{A}} \mathrm{A}$ reduced dose of rivaroxaban $15 \mathrm{mg}$ od after the initial period of $15 \mathrm{mg}$ bid dosing (ie, after $2 \mathrm{I}$ days) may be considered based on individual patient benefit-risk

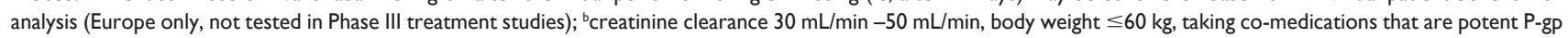
inhibitors; ' $u$ unchanged drug; ${ }^{\mathrm{d}} 33 \%$ of the dose also undergoes renal excretion as inactive metabolites. Data from previous studies.,14,23-26

Abbreviations: bid, twice daily; CYP3A4, cytochrome P450 3A4; od, once daily; P-gP, P-glycoprotein; VTE, venous thromboembolism.

anticoagulants. ${ }^{21,22}$ However, the pharmacological characteristics of NOACs (summarized in Table 3) provide particular advantages as well as challenges. ${ }^{4,14,23-26}$ Their short half-lives, for example (typically in the range of 5 hours -17 hours), are in contrast with the half-life of warfarin (mean $=40$ hours), meaning that temporary discontinuation may be sufficient to manage nonsevere bleeding. The plasma concentration of a NOAC may need to be measured in an emergency, for example, in cases of suspected overdose or serious bleeding, or when an urgent surgical procedure is required. Prolongation of a dilute thrombin time or ecarin clotting time assay may indicate clinically relevant dabigatran concentrations; an activated thromboplastin time assay may also provide a qualitative indication of dabigatran activity. ${ }^{27}$ Specific and quantitative anti-Factor Xa assays exist for apixaban and rivaroxaban, but if these are unavailable, prolongation of a suitably sensitive prothrombin time test can qualitatively indicate the presence of rivaroxaban. (This assay is not suitable for apixaban). ${ }^{27}$ Guidance for measuring edoxaban concentrations is currently lacking, but an anti-Factor Xa assay may be appropriate.

Clearance of a NOAC in a patient with renal impairment will take longer, particularly with dabigatran, which is largely dependent on renal elimination mechanisms. Dabigatran has a renal clearance of $\sim 85 \%$, whereas the values for apixaban and rivaroxaban range between $27 \%$ and $33 \%{ }^{24-26}$ Renal clearance of VKAs, by contrast, is minimal. For more severe bleeding, usual interventions such as mechanical compression (eg, in cases of epistaxis), fluid replacement, and use of blood products are suggested. ${ }^{24-26,28-30}$ Dabigatran can be dialyzed, but the other NOACs, because of their high protein binding, cannot. There is currently no specific reversal agent for any NOAC, although several are in development. ${ }^{31,32}$ Idarucizumab, a Fab fragment directed against dabigatran, is in Phase III trials and is likely to be the first such reversal agent approved for use. ${ }^{33}$ Currently, if bleeding is considered life-threatening, nonspecific prohemostatic agents, such as prothrombin complex concentrate, activated prothrombin complex concentrate, or recombinant Factor VIIa, may be used based on limited evidence, to be combined with emergency hemodynamic support (Table 4). ${ }^{24-26,28-30}$

The likelihood of bleeding in relation to NOACs can be minimized by assessing each patient's risk of bleeding and avoiding use in patients at known high risk of bleeding. These include patients with $\mathrm{CrCl}<15 \mathrm{~mL} / \mathrm{min}$ 


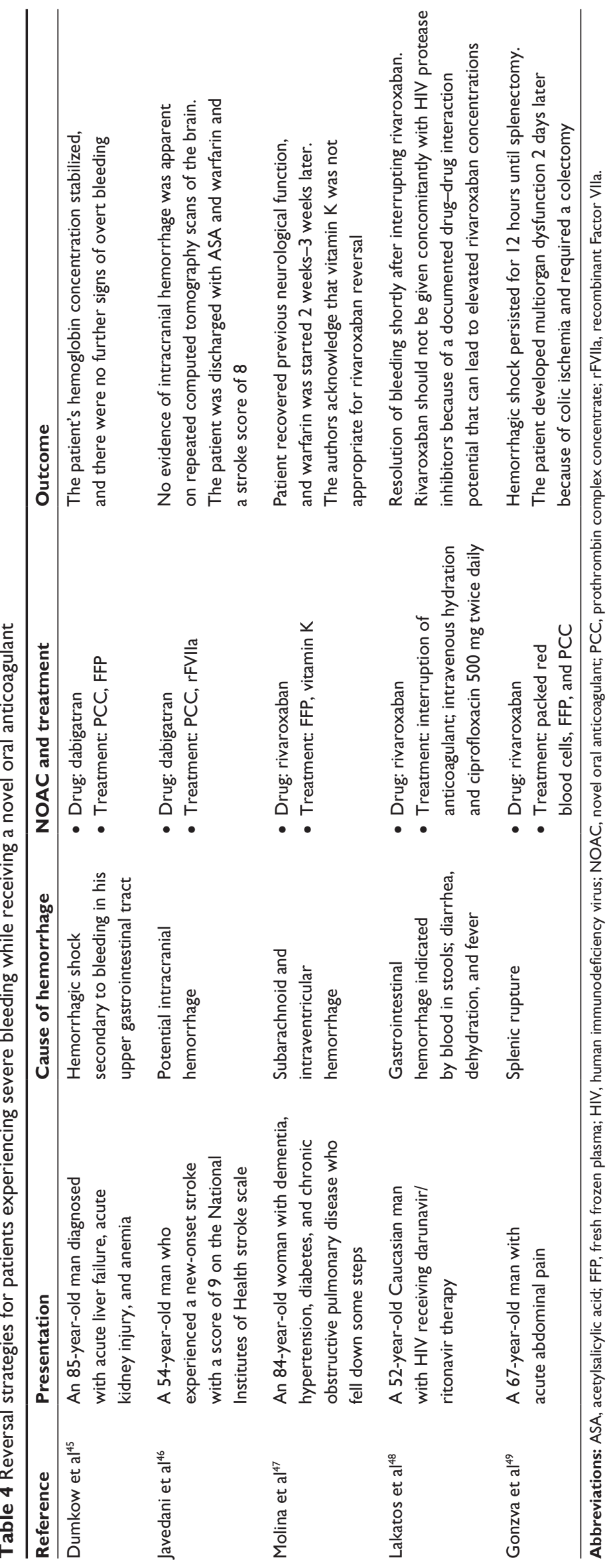


(recommendations for patients with severe renal impairment [CrCl $15 \mathrm{~mL} / \mathrm{min}-29 \mathrm{~mL} / \mathrm{min}$ ] vary by drug and region, but caution should be exercised even if it is permitted) or severe hepatic impairment (including cirrhotic patients with ChildPugh score B or C). ${ }^{24-26,28-30}$ The presence of a lesion or condition causing a clinically significant risk of major bleeding, such as a current or recent gastrointestinal ulcer, malignant neoplasm, recent brain/spinal injury or surgery, ophthalmic surgery, or recent intracranial hemorrhage, is a contraindication to NOAC treatment. ${ }^{24-26,28-30}$ Additionally, NOACs should not be given in combination with other anticoagulants (except when switching between drugs), and concomitant use of antiplatelet agents or nonsteroidal anti-inflammatory drugs increases the risk of bleeding. For rivaroxaban and apixaban, coadministration with strong inhibitors of both P-gp and cytochrome P450 3A4 is not recommended because these agents (mostly azole antimycotics and human immunodeficiency virus protease inhibitors) share the same major elimination pathways, which could lead to increased drug exposure and bleeding risk. ${ }^{24,25,28,29}$ Although not a cytochrome P450 3A4 substrate, dabigatran and its prodrug are P-gp substrates, meaning that concomitant administration with strong P-gp inhibitors can lead to clinically relevant increases in dabigatran concentrations. ${ }^{26,30}$ Edoxaban clearance is also affected by concomitant strong P-gp inhibitors. ${ }^{34}$

In all cases, the balance between the risk of bleeding and risk of VTE should be the primary factor for deciding whether to give an anticoagulant and for determining the duration of treatment.

\section{Patient needs in long-term or extended anticoagulation}

Patients requiring long-term or extended anticoagulation may find some of the limitations associated with VKA therapy, particularly regular coagulation monitoring and dietary restrictions, inconvenient in their daily lives. ${ }^{4}$ In addition to benefits in terms of reduced risk of major bleeding, the NOACs are not subject to these limitations and, therefore, simplify long-term treatment. With rivaroxaban, this has been shown to correlate with a $27 \%$ reduction in hospital admissions compared with standard LMWH/VKA treatment for patients with DVT, ${ }^{35}$ and a US model has shown that NOACs are cost saving for VTE treatment compared with standard therapy. ${ }^{36}$ Patient-reported outcomes including treatment satisfaction were assessed in the EINSTEIN DVT and EINSTEIN PE studies, by using the newly developed and validated Anti-Clot Treatment Scale (ACTS). A greater treatment satisfaction was reported in the rivaroxaban groups of both studies. In EINSTEIN DVT, the mean ACTS Burdens scores were found to be 55.2 versus 52.6 $(P<0.0001)$, and overall mean ACTS Benefits scores 11.7 versus 11.5 ( $P=0.006$ ), for rivaroxaban versus enoxaparin/VKA, respectively. ${ }^{37} \mathrm{~A}$ similar trend was seen in the PE population: mean ACTS Burdens scores were found to be 55.4 versus $51.9(P<0.0001)$, and mean ACTS Benefits scores were 11.9 versus $11.4(P<0.001) .^{38}$ The improved patient satisfaction with rivaroxaban reported in these studies ${ }^{37,38}$ is likely to have a positive impact on adherence to therapy. ${ }^{37,38}$ The use of oncedaily regimens for long-term therapy also appears to encourage adherence compared with more frequent dosing. ${ }^{39}$ This,

Table 5 Warfarin drug interaction in cancer therapy

\begin{tabular}{|c|c|c|c|c|}
\hline Reference & Presentation & $\begin{array}{l}\text { Underlying risk } \\
\text { factor for recurrent } \\
\text { thrombosis }\end{array}$ & Treatment & Outcome \\
\hline Onoda et al ${ }^{50}$ & $\begin{array}{l}\text { A 74-year-old female patient } \\
\text { diagnosed with stage IV } \\
\text { bronchioloalveolar carcinoma } \\
\text { of the lung. The patient } \\
\text { was on long-term warfarin } \\
\text { therapy because of persistent } \\
\text { atrial fibrillation }\end{array}$ & Cancer & $\begin{array}{l}\text { - Gefitinib therapy was started } \\
\text { - The daily warfarin dose was } \\
\text { decreased from } 4 \mathrm{mg} \text { to } 3 \mathrm{mg} \text {, but } \\
\text { the INR increased from } 2.0 \text { to } 2.4 \\
\text { - Daily warfarin dose was decreased } \\
\text { to } 2.5 \mathrm{mg} \text {, which returned the } \\
\text { INR to the therapeutic range }\end{array}$ & $\begin{array}{l}\text { The patient's dyspnea was } \\
\text { promptly improved, and a } \\
\text { chest X-ray taken } 6 \text { months } \\
\text { after initiation of treatment } \\
\text { revealed a considerable } \\
\text { improvement of the disease }\end{array}$ \\
\hline Saif et $\mathrm{al}^{51}$ & $\begin{array}{l}\text { A } 70 \text {-year-old female patient } \\
\text { newly diagnosed with pancreatic } \\
\text { adenocarcinoma was started } \\
\text { on anti-cancer treatment until } \\
\text { an elevation of the INR was } \\
\text { observed }\end{array}$ & Cancer & $\begin{array}{l}\text { - Immediate cessation of } \\
\text { capecitabine and cessation } \\
\text { of docetaxel after cycle } 9 \\
\text { - Gemcitabine was continued } \\
\text { every } 2 \text { weeks with close } \\
\text { monitoring of PT/INR } \\
\text { - Second-line treatment was } \\
\text { offered because of deterioration } \\
\text { but was not administered }\end{array}$ & $\begin{array}{l}\text { Elevated INR, progressive } \\
\text { disease, and clinical } \\
\text { deterioration }\end{array}$ \\
\hline
\end{tabular}

Abbreviations: INR, international normalized ratio; PT, prothrombin time. 
in turn, could reduce not only the risk of recurrent VTE but also the likelihood of long-term complications that can have a significant impact on a patient's quality of life (Table 5).

\section{Conclusion}

To reduce the risk of recurrent VTE and its associated complications, many patients will require long-term or even extended anticoagulation therapy. The limitations of traditional heparin and VKA treatment can be a burden for patients and physicians, but the development of NOACs that are both effective and potentially reduce bleeding risk substantially reduces the impact of long-term anticoagulation. The extension studies for the NOACs showed that a significant residual risk of VTE remained after 6 months -12 months of VKA therapy. Patients who received rivaroxaban or apixaban showed a significant risk reduction for recurrent VTE compared with those receiving placebo. Study outcomes suggest that current recommendations for 3 months or $>3$ months of therapy could be revised to address the high residual risk of VTE that remains after 6 months -12 months of therapy with VKAs.

\section{Acknowledgment}

The author acknowledges Jasmina Saric, who provided editorial assistance with funding from Bayer HealthCare Pharmaceuticals and Janssen Scientific Affairs, LLC.

\section{Disclosure}

The author declares no conflicts of interest in this work, and received no funding for it.

\section{References}

1. Konstantinides SV, Torbicki A, Agnelli G, et al. 2014 ESC Guidelines on the diagnosis and management of acute pulmonary embolism. Eur Heart J. 2014;35:3033-3069.

2. Kearon C, Akl EA, Comerota AJ, et al; American College of Chest Physicians. Antithrombotic therapy for VTE disease: antithrombotic therapy and prevention of thrombosis, 9th ed: American College of Chest Physicians evidence-based clinical practice guidelines. Chest. 2012;141:e419S-e494S.

3. Ageno W, Gallus AS, Wittkowsky A, Crowther M, Hylek EM, Palareti G. Oral anticoagulant therapy: antithrombotic therapy and prevention of thrombosis, 9th ed: American College of Chest Physicians evidence-based clinical practice guidelines. Chest. 2012;141: e44S-e88S.

4. Eikelboom JW, Weitz JI. New anticoagulants. Circulation. 2010;121: 1523-1532.

5. Carrier M, Rodger MA, Wells PS, Righini M, Le Gal G. Residual vein obstruction to predict the risk of recurrent venous thromboembolism in patients with deep vein thrombosis: a systematic review and metaanalysis. J Thromb Haemost. 2011;9:1119-1125.

6. Douketis J, Tosetto A, Marcucci M, et al. Patient-level meta-analysis: effect of measurement timing, threshold, and patient age on ability of D-dimer testing to assess recurrence risk after unprovoked venous thromboembolism. Ann Intern Med. 2010;153:523-531.

7. Rodger MA, Kahn SR, Wells PS, et al. Identifying unprovoked thromboembolism patients at low risk for recurrence who can discontinue anticoagulant therapy. CMAJ. 2008;179:417-426.
8. Eichinger S, Heinze G, Jandeck LM, Kyrle PA. Risk assessment of recurrence in patients with unprovoked deep vein thrombosis or pulmonary embolism: the Vienna prediction model. Circulation. 2010;121: 1630-1636.

9. Tosetto A, Iorio A, Marcucci M, et al. Predicting disease recurrence in patients with previous unprovoked venous thromboembolism: a proposed prediction score (DASH). J Thromb Haemost. 2012;10: 1019-1025.

10. Bates SM, Greer IA, Middeldorp S, Veenstra DL, Prabulos AM, Vandvik PO. VTE, thrombophilia, antithrombotic therapy, and pregnancy: antithrombotic therapy and prevention of thrombosis, 9th ed: American College of Chest Physicians evidence-based clinical practice guidelines. Chest. 2012;141:e691S-e736S.

11. The EINSTEIN Investigators. Oral rivaroxaban for symptomatic venous thromboembolism. N Engl J Med. 2010;363:2499-2510.

12. The EINSTEIN-PE Investigators. Oral rivaroxaban for the treatment of symptomatic pulmonary embolism. N Engl J Med. 2012;366: 1287-1297.

13. Agnelli G, Buller HR, Cohen A, et al; AMPLIFY Investigators. Oral apixaban for the treatment of acute venous thromboembolism. $N \mathrm{Engl}$ J Med. 2013;369:799-808.

14. The Hokusai-VTE Investigators. Edoxaban versus warfarin for the treatment of symptomatic venous thromboembolism. $N$ Engl J Med. 2013;369:1406-1415.

15. Schulman S, Kearon C, Kakkar AK, et al. Dabigatran versus warfarin in the treatment of acute venous thromboembolism. $N$ Engl J Med. 2009;361:2342-2352.

16. Schulman S, Kakkar AK, Goldhaber SZ, et al; RE-COVER II Trial Investigators. Treatment of acute venous thromboembolism with dabigatran or warfarin and pooled analysis. Circulation. 2014;129:764-772.

17. Agnelli G, Buller HR, Cohen A, et al; AMPLIFY-EXT Investigators. Apixaban for extended treatment of venous thromboembolism. $N$ Engl J Med. 2013;368:699-708.

18. Schulman S, Kearon C, Kakkar AK, et al; RE-SONATE Trial Investigators. Extended use of dabigatran, warfarin, or placebo in venous thromboembolism. $N$ Engl J Med. 2013;368:709-718.

19. Kakkos SK, Kirkilesis GI, Tsolakis IA. Editor's Choice - efficacy and safety of the new oral anticoagulants dabigatran, rivaroxaban, apixaban, and edoxaban in the treatment and secondary prevention of venous thromboembolism: a systematic review and meta-analysis of phase III trials. Eur J Vasc Endovasc Surg. 2014;48:565-575.

20. Prins MH, Lensing AW, Bauersachs R, et al; EINSTEIN Investigators. Oral rivaroxaban versus standard therapy for the treatment of symptomatic venous thromboembolism: a pooled analysis of the EINSTEIN-DVT and PE randomized studies. Thromb J. 2013;11:21.

21. Siegal DM, Crowther MA. Acute management of bleeding in patients on novel oral anticoagulants. Eur Heart J. 2013;34:489-498.

22. Heidbuchel H, Verhamme P, Alings M, et al. European Heart Rhythm Association Practical Guide on the use of new oral anticoagulants in patients with non-valvular atrial fibrillation. Europace. 2013;15: 625-651.

23. Zahir H, Matsushima N, Halim AB, et al. Edoxaban administration following enoxaparin: a pharmacodynamic, pharmacokinetic, and tolerability assessment in human subjects. Thromb Haemost. 2012;108:166-175.

24. Bayer Pharma AG. Xarelto ${ }^{\circledR}$ (rivaroxaban) Summary of Product Characteristics; 2015. Available from: http://www.ema.europa.eu/docs/en_GB/ document_library/EPAR_-_Product_Information/human/000944/ WC500057108.pdf. Accessed June 9, 2015.

25. Bristol-Myers Squibb, Pfizer. Eliquis ${ }^{\circledR}$ (apixaban) Summary of Product Characteristics; 2014. Available from: http://www.ema.europa. eu/docs/en_GB/document_library/EPAR_-_Product_Information/ human/002148/WC500107728.pdf. Accessed April 28, 2015.

26. Boehringer Ingelheim International GmbH. Pradaxa ${ }^{\circledR}$ (dabigatran etexilate) Summary of Product Characteristics; 2015. Available from: http://www.ema.europa.eu/docs/en_GB/document_library/EPAR_-_ Product_Information/human/000829/WC500041059.pdf. Accessed April 28, 2015. 
27. Blann AD, Lip GY. Laboratory monitoring of the non-vitamin $\mathrm{K}$ oral anticoagulants. J Am Coll Cardiol. 2014;64:1140-1142.

28. Janssen Pharmaceuticals Inc. Xarelto ${ }^{\circledR}$ (rivaroxaban) Prescribing Information; 2015. Available from: http:/www.xareltohcp.com/sites/ default/files/pdf/xarelto_0.pdf. Accessed June 9, 2015.

29. Bristol-Myers Squibb Company, Pfizer Inc. Eliquis ${ }^{\circledR}$ (apixaban) Prescribing Information; 2014. Available from: http://packageinserts.bms. com/pi/pi_eliquis.pdf. Accessed April 28, 2015.

30. Boehringer Ingelheim Pharmaceuticals Inc. Pradaxa ${ }^{\circledR}$ (dabigatran etexilate) Prescribing Information; 2015. Available from: http:// bidocs.boehringer-ingelheim.com/BIWebAccess/ViewServlet. ser?docBase=renetnt\&folderPath=/Prescribing\%20Information/PIs/ Pradaxa/Pradaxa.pdf. Accessed April 28, 2015.

31. Schiele F, van Ryn J, Canada K, et al. A specific antidote for dabigatran: functional and structural characterization. Blood. 2013;121: 3554-3562.

32. Lu G, DeGuzman FR, Hollenbach SJ, et al. A specific antidote for reversal of anticoagulation by direct and indirect inhibitors of coagulation Factor Xa. Nat Med. 2013;19:446-451.

33. Pollack CV Jr, Reilly PA, Bernstein R, et al. Design and rationale for RE-VERSE AD: a phase 3 study of idarucizumab, a specific reversal agent for dabigatran. Thromb Haemost. 2015;114:198-205.

34. Mikkaichi T, Yoshigae Y, Masumoto H, et al. Edoxaban transport via P-glycoprotein is a key factor for the drug's disposition. Drug Metab Dispos. 2014;42:520-528.

35. Merli GJ, Hollander JE, Lefebvre P, et al. Rates of hospitalization among patients with deep vein thrombosis before and after the introduction of rivaroxaban. Hosp Pract. 1995;2015(43):85-93.

36. Amin A, Bruno A, Trocio J, Lin J, Lingohr-Smith M. Real-world medical cost avoidance when new oral anticoagulants are used versus warfarin for venous thromboembolism in the United States. Clin Appl Thromb Hemost. Epub 2015 May 19.

37. Bamber L, Wang MY, Prins MH, et al. Patient-reported treatment satisfaction with oral rivaroxaban versus standard therapy in the treatment of acute symptomatic deep-vein thrombosis. Thromb Haemost. 2013;110:732-741.

38. Prins M, Bamber L, Cano S, Wang M, Lensing A, Bauersachs R. Patientreported treatment satisfaction with oral rivaroxaban versus standard therapy in the treatment of acute symptomatic pulmonary embolism. Blood. 2012;120:Abstract 1163.

39. Laliberté F, Bookhart BK, Nelson WW, et al. Impact of once-daily versus twice-daily dosing frequency on adherence to chronic medications among patients with venous thromboembolism. Patient. 2013;6: 213-224.
40. Citro R, Panza A, Bottiglieri G, et al. Surgical treatment of impending paradoxical embolization associated with pulmonary embolism in a patient with heterozygosis of Factor V Leiden. J Cardiovasc Med (Hagerstown). 2013;14:745-747.

41. Cook RM, Rondina MT, Horton DJ. Rivaroxaban for the long-term treatment of spontaneous ovarian vein thrombosis caused by Factor $\mathrm{V}$ Leiden homozygosity. Ann Pharmacother. 2014;48:1055-1060.

42. Jukic I, Titlic M, Tonkic A, Rosenzweig D. Cerebral venous sinus thrombosis as a recurrent thrombotic event in a patient with heterozygous prothrombin G20210A genotype after discontinuation of oral anticoagulation therapy: how long should we treat these patients with warfarin? J Thromb Thrombolysis. 2007;24:77-80.

43. Kim DI, Lee BB, Noh SI, et al. Conservative management of superior mesenteric and portal vein thrombosis associated with protein $\mathrm{C}$ and $\mathrm{S}$ deficiency. Int Angiol. 1997;16:235-238.

44. Kshatriya S, Villarreal D, Liu K. Angina pectoris in a patient with protein $\mathrm{C}$ deficiency and deep vein thrombosis: thrombus versus myxoma? Catheter Cardiovasc Interv. 2012;79:291-293.

45. Dumkow LE, Voss JR, Peters M, Jennings DL. Reversal of dabigatraninduced bleeding with a prothrombin complex concentrate and fresh frozen plasma. Am J Health Syst Pharm. 2012;69:1646-1650.

46. Javedani PP, Horowitz BZ, Clark WM, Lutsep HL. Dabigatran etexilate: management in acute ischemic stroke. Am J Crit Care. 2013;22:169-176.

47. Molina M, Hillard VH, Fekete R. Intracranial hemorrhage in patient treated with rivaroxaban. Hematol Rep. 2014;6:5283.

48. Lakatos B, Stoeckle M, Elzi L, Battegay M, Marzolini C. Gastrointestinal bleeding associated with rivaroxaban administration in a treated patient infected with human immunodeficiency virus. Swiss Med Wkly. 2014;144:w13906.

49. Gonzva J, Patricelli R, Lignac D. Spontaneus splenic rupture in a patient treated with rivaroxaban. Am J Emerg Med. 2014;32:950.

50. Onoda S, Mitsufuji H, Yanase N, et al. Drug interaction between gefitinib and warfarin. Jpn J Clin Oncol. 2005;35:478-482.

51. Saif MW, Wasif N. Interaction between capecitabine and gemcitabine with warfarin in a patient with pancreatic cancer. JOP. 2008;9:739-743.
Vascular Health and Risk Management

\section{Publish your work in this journal}

Vascular Health and Risk Management is an international, peerreviewed journal of therapeutics and risk management, focusing on concise rapid reporting of clinical studies on the processes involved in the maintenance of vascular health; the monitoring, prevention and treatment of vascular disease and its sequelae; and the involvement of

\section{Dovepress}

metabolic disorders, particularly diabetes. This journal is indexed on PubMed Central and MedLine. The manuscript management system is completely online and includes a very quick and fair peer-review system, which is all easy to use. Visit http://www.dovepress.com/ testimonials.php to read real quotes from published authors. 